\title{
Attitudes of ACES Members
}

\author{
RICHARD T. KNOWLES
}

The ACES Research Committee sent a questionnaire to a random sample of 500 ACES members in September, 1966. Returns were received from 384 members ( 77 per cent). Section I of the questionnaire dealt with background information concerning the members, and these results have been reported by Johnston (1968). The items in Section II concerned the reactions of members to services provided by ACES and APGA. Section III of the questionnaire consisted of 45 items dealing with attitudes of ACES members toward various issues in counselor education and supervision. After each item the respondent was asked to check one of the following categories: Strongly Agree, Agree, Neutral or No Opinion, Disagree, or Strongly Disagree. This report deals with the manner in which different sub-groups of ACES responded to specific items and groups of items in Section III.

The major issues dealt with in Section III were: identification with ACES as an organization, the question of broadening the membership of ACES, dues and assessments, nominations and elections, the standards issue, identification with state and local ACES associations, and innovation and change. For each of the above issues, a number of items were composed and placed randomly within the questionnaire. There were also eight issues for each of which a single item was used. These results will be discussed toward the end of this report.

\section{Major Issues}

1. Identification with ACES. Ten items were used to assess attitudes on this issue. The items and the rounded mean response (italic) are as follows:

1. Of those professional groups to which I belong, I believe I have the closest identification with ACES. Neutral.

2. I feel that my opinion is sought by the leadership of ACES. Neutral.

Richard T. Knowles is Assistant Professor of Education, University of Michigan, Ann Arbor.

†This report represents the collective effort of the ACES Research Committee composed of Donald Blocher, Chairman, Joseph Johnson, James Linden, Norman Stewart, and the author. 
3. I feel the ACES journal is an outlet for my views and ideas. Neutral.

4. I feel ACES would be a source of support for me in case of legal difficulty. Neutral.

5. I feel my geographic area is well represented in the leadership of ACES. Neutral.

6. ACES is the professional group within APGA with which I feel the closest identification. Neutral.

7. I communicate during the year with colleagues I have met through ACES. Neutral.

8. I would recommend ACES membership to colleagues. Agree.

9. I feel the views of my sub-group (Counselor Educator, State Supervisor, City Supervisor, etc.) are well represented within ACES. Neutral.

10. I feel like an ACES member in name only. ${ }^{*}$ Neutral.

'This item is scored in reverse, since it represents the opposite of the others.

In terms of this index of identification, then, the mean responses indicate a rather neutral-to-mildly-positive sense of identification with the organization.

In order to analyze the results further and to identify sub-group differences in these responses, an analysis was made of those sub-groups whose mean differed from the total group mean on each of the items. For this issue, then, we were able to assess those sub-groups with the closest identification with ACES and those with the weakest identification, as well as the specific items on which the mean of these groups differed from the total group mean.

On the issue of identification with ACES, the means of the following groups differed from the total group mean on three of these items in a positive direction. Thus, we could say that the following sub-groups within ACES have a closer identification with ACES than the general membership. They are: counselor educators from the North Central region, members from the North Central Region, counselor educators and members from the Rocky Mountain Region.

Turning to the specific items, counselor educators from the North Central Region agreed that they had the closest identification with ACES, that their geographic area was well represented in the leadership of ACES, and that they communicated regularly with other ACES members. Members from the North Central Region as a group agreed that their geographic area was well represented in the leadership of ACES, that ACES was the group within APCA with which they felt the closest identification, and that their job sub-group, whether counselor educator, state supervisor, etc., was well represented within ACES. Counselor educators as a group agreed that ACES was the professional group within APGA with which they felt the closest identification, that the views of counselor educators were well represented in ACES, but they 
disagreed that they felt like ACES members in name only. Members from the Rocky Mountain Region as a group agreed that their geographic area was well represented in ACES, that ACES was the professional group within APGA with which they felt the closest identification, but they disagreed that they felt like ACES members in name only.

Continuing with the analysis of individual items, state supervisors differed from the total membership in agreeing that they communicate regularly with ACES members and in disagreeing that they felt like ACES members in name only. The "others" category from the Rocky Mountain Region differed from the total membership in agreeing that the ACES journal was an outlet for their views. Finally, members from the Southern Region differed from the total membership in agreeing that ACES was the group within APGA with which they felt the closest identification.

So far, we have looked at the groups which felt a closer identification with ACES than the total membership. There were also some groups who felt less of an identification with ACES. However, each of these groups differed from the total membership in only one of the ten items dealing with this issue. The groups and the items on which they differed are as follows:

Those who did not respond to the region item (no region reported) and those from the Western Region who did not list a job title differed from the total membership by disagreeing that they had a closer identification with ACES than with other professional groups. Counselor educators from the Western Region and counselor educators who did not list their region differed from the total membership by disagreeing that their geographic area was well represented in the leadership of ACES. Finally, state supervisors and city directors differed from the total group by disagreeing that the views of their sub-groups were well represented in ACES.

2. Broadening ACES membership. The items dealing with this issue and the rounded mean response (italic) of the total group are as follows:

1. ACES members should encourage other related professional groups to seek membership within this organization. Neutral.

2. ACES tends to be too exclusive in its membership requirements. Disagree.

3. ACES should be an organization that exists for all pupil personnel workers, i.e., school psychologists, social workers, pupil personnel directors, etc. Neutral.

4. There are other groups that should be represented in ACES. Neutral.

5. ACES should attempt to broaden its membership. Neutral. 
6. ACES should find out which other groups might want representation in its organization and communicate such information to the members for their deliberation. Neutral.

On this issue, general satisfaction with ACES membership composition and requirements seems to exist within the total group.

On this issue, members from the Rocky Mountain Region, city directors, and "others" differed from the total group in agreeing with number six, that ACES should seek out other groups and consider their inclusion within the organization. On the other side of this issue, members from the North Central Region, counselor educators, and "others" differed from the total group in disagreeing with item three, that ACES should be an organization for all pupil personnel workers, i.e., school psychologists, social workers, pupil personnel directors, etc.

3. Dues and assessments. The items dealing with this issue and the rounded mean response (italic) of the total group are as follows:

1. I fiind the current dues to be reasonable. Agree.

2. If the organization offered good reason to increase dues, I would not find this action objectionable. Neutral.

3. I favor special assessment by ACES to carry through projects that we endorse as an organization. Neutral.

4. Only activities that can be carried out within the existing budget of ACES should be considered by the organization. "Neutral.

- This item is scored in reverse, since it represents the opposite of the others.

Again, on this issue total membership reflect neutral-to-mildlypositive attitudes toward dues policies.

On this issue, the only sub-group that differed from the total group were "others" from the Rocky Mountain Region. They differed by agreeing with item three, that special assessments should be made by ACES to carry through favored projects.

4. Nominations and elections. The items dealing with this issue and the recorded mean response (italic) of the total group are as follows:

1, Our present system of nominating candidates for offices in ACES is satisfactory. Agree.

2. It would not be out of the ordinary for me to nominate a colleague for office in ACES. Neutral.

3. Offices in this organization tend to be held too much by members identified with some particular point of view. "Neutral.

4. The position within our organization tend to be filled too often by the same individuals. ${ }^{\circ}$ Neutral.

-This item is scored in reverse, since it represents the opposite of the others.

Again, general attitudes are mildly positive.

On this issue a number of sub-groups differed by responding Neutral rather than Agree to item one. They are as follows: members from the 
North Atlantic Region, those who reported no region, state supervisors, "others," APA members, counselor educators from the North Atlantic Region, and counselor educators from the North Central Region. Each of these groups was neutral on the question of satisfaction with present nominating procedures. In the same vein, state supervisors from the Rocky Mountain Region agreed that the positions within our organization tend to be filled too often by the same individuals.

On the other side of this issue, general membership from the Rocky Mountain Region disagreed that these positions tend to be filled by the same individuals. Along with them, counselor educators from the Rocky Mountain Region and those with other job titles from the Rocky Mountain Region differed from the total group in agreeing that it would not be out of the ordinary for them to nominate a colleague for an ACES office.

5. Counselor education standards. The items dealing with this issue and the rounded mean response (italic) of the total group are as follows:

1. I would endorse the work thus far by ACES on Standards for Counselor Education. Agree.

2. ACES should now set up more effective ways to enforce the Standards for Counselor Education. Agree.

3. Standards is not an issue for ACES to concern itself with any longer. "Disagree.

4. Colleagues in my place of work are not yet ready to apply the Standards for Counselor Education. ${ }^{\circ}$ Neutral.

5. The approach to implementation of the Standards for Counselor Education has thus far not been too successful. "Neutral.

6. There must be a better way to implement the ACES Standards for Counselor Education than our current approach. "Neutral.

'This item is scored in reverse, since it represents the opposite of the others.

On this issue counselor educators from the Rocky Mountain Region and those with "other" job titles from the North Central Region differed from the total group by replying Neutral instead of Agree to item two, ACES should set up more effective ways to enforce the Standards. State Supervisors and members from the Rocky Mountain Region differed by agreeing that there must be a better way to implement the Standards than our current approach.

On the other side of this issue, counselor educators, members from the Rocky Mountain Region, members who didn't list a region and those with "other" job titles from the North Atlantic Region differed from the others by agreeing that their colleagues were ready to apply the Standards. On the issue of Standards in general, the total membership endorsed the work done on Standards more than any of the other issues. 
6. State and local ACES groups. The items dealing with this issue and the rounded mean response (italic) of the total group are as follows:

1. The state ACES group is a group with which I can identify. Neutral.

2. State and local organizations of ACES members should be radically changed. "Neutral.

3. Local ACES groups add up to just one more organizational meeting we can do without. "Neutral.

4. There is little benefit in currently existing state or local organizations of ACES members. ${ }^{\circ}$ Neutral.

- This item is scored in reverse, since it represents the opposite of the others.

Little overall enthusiasm for state ACES branches was evidenced. On this issue, there were differences on only item three. Members from the North Central, Southern and Rocky Mountain Regions and non-APA members disagreed that local ACES group meetings should be discontinued. Apparently, these groups identify more with local associations than do the others.

7. Innovation and change. The items dealing with this issue and the rounded mean response (italic) of the total group are as follows:

1. I would characterize ACES as a vibrant, forward-looking organization. Neutral.

2. Compared with other organizations within APGA, ACES can look with pride to its responsiveness to changing conditions. Neutral.

3. ACES seems too tied to traditional ways of professional organizations. Neutral.

- This item is scored in reverse, since it represents the opposite of the others.

On item two, ACES' responsiveness to changing conditions, a number of groups were pleased with ACES' progress. They are: city directors, state supervisors with no region reported, non-APA members, and members from the North Central, Southern, and Rocky Mountain Regions.

\section{Other Issues}

In addition to the seven major issues cited above, individual items were also included to tap specific issues. The items with which all members agreed without exception were:

1. ACES ought to explore further and more rapidly the international guidance scene.

2. ACES should take an active role in affecting national legislation.

3. We need a consistent effort to find ways of introducing innovations into counselor education and supervision.

4. ACES needs to maintain a strong personal identity within APGA.

There were also some interesting single items on which groups differed markedly. On the item "Only those programs that have three or more full-time counselor educators should be allowed to certify people in guidance," counselor educators from the Rocky Region agreed; the total group was neutral; and counselor educators with no region 
reported disagreed. Perhaps the response is related to the adequacy of existing programs.

Another item which revealed differences stated, "There is an excessive emphasis on psychology in most counselor education programs." No group agreed, the total membership was neutral, and the following groups disagreed: counselor educators, those with "other" job titles, APA members (no surprise), and members from the North Central, Rocky Mountain, Western Regions.

An item calling for a separate organization for counselor educators, state supervisors, and city directors had none agreeing, the total group neutral, and the following groups disagreeing: counselor educators from the North Central and Rocky Mountain Regions, those with "other" job titles from the North Atlantic and Southern Regions, APA members, those with "other" job titles and members from the North Central and Western Regions. Finally, everyone except counselor educators reporting no region agreed that this type of survey should be continued.

\section{Profiles of Various Sub-Groups}

In addition to the general results cited above, it is now possible to draw up a profile of the various sub-groups in ACES which will indicate the issues on which they differ from the total group, including their attitudes toward these issues.

Let's start with sub-groups according to job title. How do counselor educators, state supervisors, city directors, and "others" differ from the total membership on the issues studied?

1. Counselor educators differed from the total membership on the issue of identification with ACES. More than others, they felt ACES was the professional group within APGA with which they felt the closest association, that the views of counselor educators were well represented within ACES, and that they did not feel like ACES members in name only. On the issue of broadening membership, they did not feel that ACES should be an organization for all pupil personnel workers (school psychologists, social workers, pupil personnel directors, etc.), whereas the total membership was neutral on this issue. On the issue of standards, they felt more than others that colleagues in their place of work were ready to apply the Standards for Counselor Education. On the issue of psychology in counselor education, they disagreed that there was an excessive emphasis on psychology in counselor education programs, whereas the total membership was neutral on this issue.

2. State supervisors also differed from the total group on the issue 
of identification with ACES. More than others, they said they communicated regularly with other ACES members and that they did not feel like ACES members in name only. However, they did not feel that the views of state supervisors were well represented in ACES. They were also neutral on the issue of satisfaction with nominating procedures, whereas the total group was satisfied with them.

3. City directors did not feel that their group was well represented in ACES. They agreed that ACES should seek out other groups for inclusion within the organization, whereas the total group was neutral on this issue. They were more pleased with ACES' responsiveness to changing conditions than was the membership in general.

4. The "others" group (those who did not classify themselves as one of the above three) also agreed that ACES should seek out other groups for inclusion within the organization. They also disagreed that there should be separate organizations for counselor educators, state supervisors, and city directors. They also did not feel that there was an excessive emphasis on psychology in counselor education programs.

Profiles may also be obtained for regional sub-groups. How do members from the Rocky Mountain, North Central, Southern, Western, and North Atlantic Regions differ from the total membership on specific issues?

1. Rocky Mountain Region members differed from the total membership on more issues than members from other regions. However, most of the differences stemmed from a more positive attitude toward ACES and its policies. For example, these members felt a closer identity with ACES than with other professional groups, including the various branches of APGA. They felt their geographic area was well represented in the leadership of ACES, and they denied feeling like ACES members in name only. They agreed that ACES should seek out other professional groups for inclusion within the organization, and they disagreed that the same individuals filled leadership positions in ACES. On the standards issue, they said their colleagues were ready to apply the Standards, and they wanted better means of enforcing the Standards. They were pleased with ACES' responsiveness to changing conditions and disagreed that there was too much emphasis on psychology in counselor education programs. They also did not feel that state and local associations of ACES members should be discontinued.

2. North Central Region members also differed from the total group on a number of issues, also displaying a more positive attitude toward ACES than the general membership. They agreed that ACES 
was the branch of APGA with which they felt the closest identification, and they also felt that their geographic area and job title subgroups were well represented in ACES. They differed from the total membership in the feeling that ACES should not be for all pupil personnel workers (school psychologists, social workers, pupil personnel directors, etc.), perhaps displaying an exclusive in-group feeling. They disagreed that local ACES groups should be discontinued, and they were pleased with ACES' responsiveness to changing conditions. They also disagreed that there was too much emphasis on psychology in counselor education programs and that there should be a separate organization for counselor educators, state supervisors and city directors.

3. Southern Region members differed from the total group on only three issues, all indicating a positive attitude toward ACES, although not as strong as the above mentioned regions. They agreed that ACES was the branch of APGA with which they felt the closest identity and disagreed that local ACES groups should be discontinued. They were also pleased with ACES' responsiveness to changing conditions.

4. Western Region members differed from the total group on only two issues, indicating more of a neutral attitude toward the organization than the other three groups. They disagreed that there was too much emphasis on psychology in counselor education programs, and they did not want a separate organization for counselor educators, state supervisors, and city directors.

5. North Atlantic Region members were the least positive of the regional groups, differing from the total group on only one issue. They were neutral on satisfaction with nominating procedures for ACES offices, whereas the total group was satisfied with these procedures.

Profiles for combinations of the above groups may also be obtained, although these results will not be reported here. Suffice it to say that it is possible to obtain similar profiles for counselor educators from the North Central Region, state supervisors from the Rocky Mountain Region, etc.

Other sets of profiles are also available and perhaps one could be mentioned here. ACES members who also belong to APA differed from the total group on three issues. They were neutral on satisfaction with nomination procedures, whereas the total group was satisfied. As would be expected, they disagreed that there was an excessive emphasis on psychology in counselor education programs. They also did not agree that there should be a separate organization for counselor educators, state supervisors, and city directors. ACES members who 
were not also members of APA differed from the total group in being pleased with ACES responsiveness to changing conditions and in disagreeing that local ACES groups should be discontinued.

It should be remembered that the ACES members sampled were not very different in their overall responses. The differences discussed above were highlighted because of the nature of the analysis.

\section{REFERENCE}

Jomnston, J. A. Membership in ACES, Counselor Education and Supervision, Winter, $1968,7,137-42$.

(Received October 12, 1967) 